\title{
NOTE
}

\section{The Ebb and Flow of the Democratization Process in Africa}

DOI http://dx.doi.org/10.4314/mlr.v15i1.11

Aschalew Ashagre Byness *

\begin{abstract}
Democracy and democratization are two faces of a coin, and democracy is unattainable in the absence of the democratization process. This note deals with some salient points regarding the processes, challenges and obstacles of democratization in Africa since the early 1960s. The roles of traditional institutions for democratization in Africa have also been highlighted. I argue that the democratization process in Africa is characterized by ebb and flow. There are various challenges and obstacles to democratization in spite of strong aspirations. Yet, Africa should strive hard to overcome these challenges and obstacles since it has no choice other than democratization.
\end{abstract}

\section{Key terms}

Africa $\cdot$ Democratization $\cdot$ Challenges $\cdot$ Obstacles $\cdot$ Traditional institutions

\section{Suggested citation:}

Aschalew Ashagre Byness (2021), 'The Ebb and Flow of the Democratization

Process in Africa', 15 Mizan Law Review 1: 297-312.

\section{Introduction}

Democracy and democratization are the concern of countries, governments, international institutions, scholars, politicians and the public at large. In post-colonial Africa, there are various issues surrounding democracy and democratization. Although numerous researches have been conducted, issues and problems concerning democracy and democratization in this continent have not yet been exhaustively addressed. Owing to continental and

- Aschalew Ashagre Byness: Assistant Professor of Law, School of Law, Addis Ababa University; Consultant and Attorney at law; PhD candidate.

ORCID: https://orcid.org/0000-0002-1970-7554

E-mail: gakidan.ashagre335@gmail.com

I thank Dr. Getachew Assefa (Associate Professor of Constitutional Law) for his constructive comments on the earlier draft of this paper. 
international economic, political and social dynamics, the discussion and arguments on democracy and democratization are thus still underway.

This note is based on doctrinal research and has examined the relevant academic literature. It is meant to complement an article on African democracy that was previously published. ${ }^{1}$ The following section deals with preliminary points on democratization. Section 3 discusses democratization in post-colonial Africa from 1960 to 1990 . The fourth section reviews the democratization process during the post-1990s. Section 5 addresses some important points concerning the challenges and obstacles to democratization in Africa from the 1990s to date, followed by the sixth section that highlights the role of traditional institutions in the democratization process.

\section{Preliminary Points on Democratization}

According to, John T. Ishiyama ${ }^{2}$,

Democratization is the process by which societies develop toward democracy. Some ... define democratization as the extension of citizenship and the franchise. Yet, this presupposes that meaningful elections take place and that political elites will abide by outcomes of such elections, which implies at least the notion that a rule of law exists and that leaders are accountable to someone. On the other hand, if we consider the minimal definition of democracy as the rule of law, the development of the institutions of civil society, the practice of free and fair elections and the establishment of accountability of those who govern, then democratization is the process by which the rule of law, elections and leadership accountability is established, and where civil society develops. Once established, the expansion of democracy involves extending the degree of competition and participation, through such mechanisms as broader enfranchisement (participation) and greater competition.

It is generally agreed among scholars that the route to democracy/the democratization process is not abrupt and dramatic; rather, it is a gradual and staged process. Yet, there is no agreement on the number of stages to the process. According to Schmitter and O'Donnell, there are two broad phases which lead to democratic outcomes: liberalization and democratization.

\footnotetext{
${ }^{1}$ See Aschalew Ashagre (2017), 'Reflections on African Democracy: The Rugged

Terrain of the Past, Current Challenges and Issues of Contextualization', Journal of Ethiopian Law, Vol. 29, No.1, pp. 107-125.

2 John T. Ishiyama (2012), Comparative Politics Principles of Democracy and Democratization, Wiley-Blackwell, p. 30.
} 
These authors refer to transition as the interval between one political regime and another. The beginning of the transition from authoritarianism is highly uncertain although the key symptom is the weakening or crumbling of the incumbent regime and when its ideologies and politics are seriously questioned and challenged. Under such settings, leaders themselves may set the process in motion by embarking on liberalization policies which involve a combination of loosened restrictions and expanded individual and group rights. $^{3}$

Democratization involves more than the mere extension of political rights since it also has social and economic dimensions within which things operate on democratic lines. The implementation of liberalization process can set the stage of democratization as liberalization usually comes before democratization. Nonetheless, there are situations where there is an overlapping of the two processes. ${ }^{4}$

As far as its essence is concerned, democratization is understood to mean the development of more egalitarian social relations accompanied by the elimination of autocratic structures. In a democratization process, the state is expected to lessen its involvement in the economy and economic policies that give more attention to labour. The process also allows grass roots, nongovernmental, nonpartisan, social and political associations to flourish which enhance the habits of democratic participation by citizens. ${ }^{5}$

\section{Democratization in Post-colonial Africa: From the 1960s to the 1990's}

Although many African states achieved independence since the 1960's, democratization remained a nightmare in the continent until the 1990s. As Samuel Decalo noted, during this period there was a belief that African states would not move in the direction of democratization owing to their poverty and violent political reality. ${ }^{6}$ Chabal argued that 'to have democracy to flourish [in Africa] would have been a historical blindness since outside the core [industrialized states] democracy is a rarity. ${ }^{97}$ In fact, writers argued

${ }^{3}$ Edmond J Keller (1995), 'Liberalization, Democratization and Democracy in Africa: Comparative Perspectives', Africa Insight, Vol. 25, No. 4, p. 224.

${ }^{4}$ Ibid.

${ }^{5} \mathrm{Id}$. at 225.

${ }^{6}$ Samuel Decalo (1992), 'The Processes, Prospects and Constraints of Democratization', Africa, African Affairs, Vol. 91, No. 362 (Jan., 1992), p. 7.

${ }^{7}$ See P. Chabal, ed. (1986), Political Domination in Africa: Reflections on the Limits of Power, (Cambridge University Press, Cambridge), p. 5. 
that democratization would not be a reality in the continent having understood the beliefs and resolutions of the post-independence leaders of various states of Africa. This is because the leaders believed that competitive politics, an essential manifestation of democratization, was an imported luxury, which was not necessary and affordable in developing countries.

The leaders firmly believed that multiplicity of political parties would merely mirror and politicize the existing ethnic, clan, regional and religious cleavages. The leaders believed also that these are sources of political support and power which could easily be mobilized in Africa. In this regard, Sierra Leone's president Siaka considered multi-partism as 'a system of institutionalized tribal and ethnic warfare euphemistically known as election which contributes to an open anarchy and disunity. ${ }^{8}$

This view was also shared by Tanzanian's president Julius Nyerere who was quoted to have said 'when there is one party, and that party is identified with the nation as a whole, the foundations of democracy are firmer than they can ever be where you have two or more parties, each representing a section of the community. ${ }^{9}$ In Malawi, the idea of opposition party was utterly rejected in the early 1960s under the guise of theological grounds. The then president of Malawi, Hastings Banda, said, 'there is no opposition in Heaven; God Himself does not want opposition; that is why He chased Satan away. ${ }^{10}$ (Emphasis added)

Yet, the single party system was used benevolently in certain African countries. Cases in point were Julius Nyerere, Kenneth Kaunda and Felix Houphouet Boigny (in Tanzania, Zambia and Ivory Coast respectively) although there were other leaders who ruled their society very harshly. In any case, the hegemonic single party state became an autocratic patrimonial state which was detached from the vital creative energies of the African people and their societies regardless of the fact that the ideology followed by a state concerned was capitalism, 'African Socialism', or Marxism. This hegemonic single party state produced presidential authoritarianism although the degrees of repression could vary from state to state. ${ }^{11}$

\footnotetext{
${ }^{8}$ Samuel Decalo, supra note 6, at10.

${ }^{9}$ Ibid; see also Julius K. Nyerere (1966), Freedom and Unity (Oxford University Press, Dar-Es-Salaam), p. 196.

${ }^{10}$ Samuel Decalo, supra note 6, at 10

${ }^{11} I d$. at 12 .
} 


\section{The Post 1990s Democratization Process in Africa}

\subsection{Military intervention as an obstruction to democratization?}

The first three decades of post-independence Africa were known for the high incidence of successful military coups which installed military regimes. There were also a number of military plots and coups which were not successful. The prevalence of these realities prevented the flourishing of democratization in the continent. ${ }^{12}$ Unfortunately, the democratization process even after the 1990s witnessed the presence of military coups. Studies show that there were fifty attempted coups from 1990 to 2001 in sub-Saharan Africa, of which 13 were successful. ${ }^{13}$ For example, although a multiparty election was introduced in 1994 in Guinea Bissau, it was followed by successful coups in 1999 and 2003 while president Vieira was killed by soldiers in 2009. In 2003, a rebel leader was able to oust the elected president of the Central African Republic. Military coups were also witnessed in Togo, Mauritania (2008), Guinea (2008), Niger (2010). ${ }^{14}$

However, military interventions and rules have been declared illegitimate, and this was reflected by actions taken by the Organization of African Union (OAU) and its successor- African Union (AU). In 1999, the OAU declared that it would not give any recognition to change of regime by military coup. ${ }^{15}$ In 2000, the organization's Assembly institutionalized rejection of unconstitutional change of government. ${ }^{16}$ The AU also took important steps in this regard. It issued the African Charter on Democracy, Election and Governance in 2004 which was meant to enhance democracy and democratization in Africa, and to deny recognition to unconstitutional regime change. ${ }^{17}$ In this regard, the AU had temporarily suspended

${ }^{12}$ Kristen A. Harkness (2016), 'The Ethnic Army and the State: Explaining Coup Traps and the Difficulties of Democratization in Africa', Journal of Conflict Resolution, Vol. 60, No.4, pp. 587-616. For analysis of the impact of coups on democratization, see also Clayton L. Thyne and Jonathan M. Powell (2014), 'Coup D'état or Coup D'autocracy? How Coups Impact Democratization, 1950-2081', Foreign Policy Analysis, available at

www.Uky.Edu/ Clthyn2/Thyne_Powell_Fpa2013.Pdf, accessed on February 2, 2018, pp. $1-22$.

${ }^{13}$ See Gabrielle Lynch and Gordon Crawford (2011), 'Democratization in Africa 19902010: An Assessment,' Democratization, Vol. 18, No.2, at 277.

${ }^{14}$ Id. at 278 .

${ }^{15}$ Ibid.

${ }^{16}$ Ibid.

${ }^{17}$ See The African Charter on Democracy, Election and Governance, 2004, available at Archive.Ipu.Org/Idd-E/Afr_Charter.Pdf, accessed on February 5, 2018. 
Mauritania's and Niger's membership to AU in 2008 and 2010 respectively following the coups that occurred in these countries. ${ }^{18}$

\subsection{Gains and shortfalls of the democratization process}

\subsubsection{Elections as springboard for democratization: Half full and half empty?}

In spite of many irregularities and deficiencies of democratization in Africa, there have been certain improvements. Before 1989, it was only Botswana and Mauritius which held regular multiparty elections. Since the 1990s, however, most African countries held elections which are taken as a positive move towards democratization even though some elections did not lead to peaceful transfer of power. On the positive front, there were elections that resulted in peaceful transfer of power. Good examples in this regard were Zambia and Cape Verde in 1991, Benin in 1991 and 2006, South Africa in 1994, Senegal in 2000. Generally speaking, there was no ousting of incumbent presidents despite the presence of elections. ${ }^{19}$

Election is a fundamental element of democratization as it is not possible to install democratic governments and broader democratic consolidation in the absence of elections. In this regard, Staffan Lindberg argues that there is an inherent value in holding elections even if there may be elections that are not free and fair. ${ }^{20}$ Others argue that Lindberg underestimates the cost of poorly governed elections by citing several examples of elections which led to democratic rollback (such as in Kenya 2002, Nigeria 2006, Zimbabwe 2008, Ethiopia 2005, Senegal, Cameroon and the like.) ${ }^{21}$ During the period under discussion, some countries continued to undergo democratization while others saw democratic recession which shows that it is hardly possible to lump African regimes together as imperfect democracies. ${ }^{22}$ Rather, Africa

${ }^{18}$ Gabrielle Lynch and Gordon Crawford, supra note 13, p. 278.

${ }^{19} \mathrm{Id}$. at 279. It is argued that the recurrence of elections during the period under discussion would represent a meaningfully different situation as compared to the previous post independence decades in which elected governments did not have the chance of survival to the end of their term owing to the military intervention. For instance, ousting of elected governments by military intervention occurred in Ghana from the 1960s to 1980 s. In addition to military intervention, the post-independence Africa was known for one party state with long incumbency of presidents and ruling parties as in Kenya, Tanzania, Zambia and Malawi from the 1960s to the 1990s.

${ }^{20}$ Staffan Lindberg (2006), 'The Surprising Significance of African Elections,' Journal of Democracy, Vol.17, p. 40.

${ }^{21}$ Lynch and Crawford, supra note 13, at 280.

${ }^{22}$ Van De Walle (2002), 'Africa’s Range of Regimes', Journal of Democracy, Vol.13, p. 67. 
has witnessed hybrid regimes which are neither fully democratic nor classically authoritarian. ${ }^{23}$ African democracies can be classified as defective democracies or competitive authoritarianism since they fail to meet the most accepted minimum standards of democratization. ${ }^{24}$

Such a hybrid regime becomes a reality through three major mechanisms. The first one is 'menu of manipulation or range of tactics from which rulers may choose to help them carve the democratic heart out of electoral contests; ${ }^{25}$ The second mechanism relates to "the fallacy of 'electoralism' and the fact that elections may confer little real institutional or structural change and can actually be associated with the thinning out of more substantive forms of democracy." The third scenario is attributable to an international community that claims to stand for the promotion of democracy but in real terms seems more interested in political stability and economic growth at the expense of democracy. ${ }^{26}$ Concerning the first variant of the hybrid regime, Diamond noted that:

elections are fair only when there is a neutral, competent, and resourceful electoral authority; security forces and the judiciary are impartial in their treatment of candidates and parties; access to media to contenders, electoral districts and rules do not systematically disadvantage the opposition; there is a secret ballot and transparent rules for vote counting and there are clear and impartial procedures for resolving complaints and disputes. ${ }^{27}$

His argument shows the various ways in which leaders can manipulate and subvert the electoral process. In this regard, the readiness of political elites to resort to political violence -which includes the sponsorship of informal repression or covert violations by third parties- and resort to informal disenfranchisement are very much worrisome. According to Lynch and Crawford, informal disenfranchisement manifests itself through 'ethnic cleansing to the introduction of universal but discriminatory registration methods, identification requirements, and voting procedures. ${ }^{28}$

${ }^{23}$ Matthijs Bogaards (2009), 'How To Classify Hybrid Regimes? Defective Democracy and Electoral Authoritarianism', Democratization, Vol. 16, pp. 399-423.

${ }^{24}$ Steven Levitsky and Lucan Way (2002), 'The Rise of Competitive Authoritarianism', Journal of Democracy, Vol.13, p. 52.

${ }^{25}$ Andreas Schedler (2002), 'The Menu of Manipulation', Journal of Democracy, Vol.13, pp. 41-42.

${ }^{26}$ Lynch and Crawford, supra note 13, at 281.

${ }^{27}$ See Larry Diamond (2002), 'Thinking about Hybrid Regimes', Journal of Democracy, Vol.13, 2002, pp. 21-35.

${ }^{28}$ Lynch and Crawford, supra note 13, at 282. 
For instance, as studies have demonstrated, state sponsored ethnic clashes in Kenya in 1990s displaced and effectively disenfranchised potential opposition voters across much of the Rift Valley, and this demonstrates how informal repression can be instrumental to informal disenfranchisement and political mobilization and intimidation. ${ }^{29}$ As Lynch and Crawford noted:

....while elections are important as the opening moves in a long drawn out drama in which different social forces seek to control the states, it is a drama that is not necessarily linear or progressive. Elections can enhance competition, open political spaces and enable struggle, but they can also legitimize authoritarian regimes, create new regime types and prompt new political crises and human rights abuses. Such partial progress is due to the fact that the ruling elites often embrace multiparty elections as a survival strategy and regularly win them by using the advantage of incumbency with little international outrage. ${ }^{30}$

\subsubsection{The bid towards the institutionalization of separate powers: Achievements and pitfalls}

In Africa, there have been attempts to institutionalize the separation of powers. In this regard, across the Sub-Saharan Africa, formal institutional rules are drawing attention much more than they used to, and have displaced violence as the primary source of constraints on executive behaviour. ${ }^{31}$ Examples in this regard include handover of power via elections, term limits of presidents, and the abortion of attempts by some presidential incumbents to manipulate their constitutions to avoid term limits.

The cases of Nigeria and Zambia illustrate this reality. In Nigeria, the senate rejected a bill that would have enabled Obasanjo to run for a third term; and in Zambia, president Chiluba was compelled to restrain from attempts toward constitutional change since he faced serious opposition from the parliament and his own party. ${ }^{32}$ These positive developments show that increasing institutionalization of political power in Africa -whereby power changes hands principally in accordance with institutional rules- would be a very useful step towards democratization in the Africa. ${ }^{33}$

${ }^{29}$ Ibid.

${ }^{30}$ Ibid.

${ }^{31}$ See Daniel Posner and Daniel J. Young (2007), 'The Institutionalization of Political Power in Africa', Journal of Democracy, Vol. 18, p. 127.

${ }^{32} I d$. at 133. There are also several manipulations of term limits in Africa. In this regard, see Denis M. Tull and Claudia Simons (2017), 'The Institutionalization of Power Revisited: Presidential Term Limits', in Africa, Africa Spectrum 2/2017: 79-102.

${ }^{33}$ Posner and Young, supra note 31, at 129. 
However, Richard Joseph argued that that 'the struggle to cross the frontier from personal rule to rule-based governance is still far from over in much of Africa.' He mentioned two good examples. The first example was Musevini's successful attempt to extend his presidential term and the second was the violence following the 2007 election in Kenya. ${ }^{34}$ Likewise, Oda van Cranenburgh, having studied 30 Sub-Saharan African countries, argued that big men continue to rule and she highlighted high level of the institutional powers of presidents showing that the difference between democracies and non-democracies is blurred as far as the power of the president is concerned. ${ }^{35}$ As Vanter observes, the legislative branch has not been playing meaningful roles in contrast to the powers of African presidents. ${ }^{36}$ Still worse is the insignificant role of the judiciary in Africa as an instrument of enhancing democratization without prejudice to few exceptions. ${ }^{37}$

\subsubsection{Political parties and issue-based politics}

African democratic movement of the post 1990s has resulted in the proliferation of political parties, and this can be taken as a positive move since the proper functioning of political parties is indispensable. ${ }^{38}$ However, political parties in Africa do not seem to be important contributors to demoralization because they are unstable, with parties appearing and disappearing from one election to another. They are also blamed for weak organizations and weak internal democracy. ${ }^{39}$ Opposition parties in Africa also manifest fragmentation. In general, the African multiparty system is

34 See Richard Joseph (2008), “Challenges of A 'Frontier' Region”, Journal of Democracy, Vol. 19, pp. 94-108.

35 Oda Van Cranenburgh (2008), "Big Men" Rule: Presidential Power, Regime Type and Democracy in 30 African Countries, Democracy, Vol.15, p .952.

36 See Francois Venter, 'Parliamentary Sovereignty or Presidential Imperialism? The Difficulties in Identifying the Source of Constitutional Power from the Interaction between Legislatures and Executives in Anglophone Africa', in Charles M. Fombad (ed.), Separation of Powers in African Constitutionalism, Oxford University Press, (2016), pp. 96-133.

${ }^{37}$ See Fernando Loureiro Bastos, 'An Overview of Judicial and Executive Relations in Lusophone Africa', in Charles M. Fombad (ed.), Separation of Powers in African Constitutionalism, Oxford University Press, (2016), pp.159-201.

${ }^{38}$ M. A. Mohamed Salih \& Per Nordlund (2007), 'Political Parties in Africa: Challenges for Sustained Multiparty Democracy, Africa Regional Report Based on Research and Dialogue with Political Parties, International Institute for Democracy and Electoral Assistance', available at www.Msu.Ac.Zw/Elearning/Material/1257171344africa_Report_Inlay_Final.Pdf, accessed on January 15, 2018.

${ }^{39}$ Lynch and Crawford, supra note 13, at 285-286. 
known for critical fluidity or lack of institutionalization, the dominance of the ruling parties, the unrepresentative nature of the political parties, patterns of ethnic voting and the absence of issue-based politics. ${ }^{40}$

\subsubsection{Emergence of civil societies}

Although civil societies play important roles in the process of democratization, their roles (in this regard) in various African countries are not that much influential in the bid to create legitimate governments and prevent political decay. ${ }^{41}$ It is argued that the civil society organizations in Africa include ethnic and religious organizations dominated by a narrow base of elites, unorganized protest and neo-patrimonial relationships between the state and nearly all organizations. ${ }^{42}$

However, there are some exceptions to the above generalization where civil societies have been playing positive roles towards the enhancement of democratization in the continent. Ghana is a good example as it has put in place constitutional provisions which have guaranteed and facilitated the proliferation of civil society organizations. Because of this constitutional guarantee, civil societies in Ghana significantly engage with the government in the course of policy making processes. Moreover, dense and vibrant civil society organizations have emerged in Nigeria and Kenya, and they have been playing meaningful roles towards democratization. ${ }^{43}$

\section{Challenges and Obstacles to Democratization in Africa}

In spite of attempts for the realization of democratization in the continent since the 1990s, the democratization process has encountered various challenges.

\subsection{Institutional Challenges}

One of the major challenges to democratization is to develop and strengthen competent institutions of democracy such as the media, electoral systems, judiciary, civil service, independent commissions and educational institutions. Many of these institutions are not functioning based on rule of law, independence, institutional capacity, impartiality, good governance and public confidence. For instance, the judiciary is not independent in many African states. It is usually understaffed, underfunded, and its survival is at

\footnotetext{
${ }^{40}$ Ibid.

${ }^{41}$ See John W. Harbeson, Donald Rotchild and Naomi Chazan (1994), Civil Society and the State in Africa, (Boulder, Co. Lynne Rienner), pp. 1-2.

${ }^{42}$ Lynch and Crawford, supra note 13, at 285.

${ }^{43}$ Ibid.
} 
the mercy of any government in power. ${ }^{44}$ Another institutional challenge comes from the absence of an independent and free media while it is a critical component of democratization in ensuring freedom of expression, promoting free flow of information and ideas and facilitating informed decisions. However, the media has been exposed to harassment and journalists have been victims of arbitrary arrest and detention. ${ }^{45}$ Thirdly, institutionalizing civil societies has remained a daunting task although there have been positive developments. ${ }^{46}$

\subsection{Poverty and Illiteracy}

Although there are positive developments in the continent, poverty is still an acute problem for most African countries due to various natural and artificial causes. It is argued that poverty is a great hindrance to democratization and the enjoyment of human rights since democratization cannot flourish in the presence of humiliating poverty. ${ }^{47}$ Most constitutions in Africa require a primary or secondary certificate as an indispensable condition to run for elected positions. However, illiteracy is a problem in Africa. ${ }^{48}$ In addition, the right to education is a non-justiciable matter in most African constitutions except the constitutions of some countries such as South Africa and Algeria. ${ }^{49}$ Therefore, illiteracy still remains a serious menace to democratization in the continent.

\subsection{Corruption}

Africa has been plagued with corruption, and government institutions in Africa have become breeding grounds for corrupt practices. In particular, political corruption has adversely affected democracy and democratization. It is indeed unthinkable to strengthen the institutions of democracy, to bring about, enhance and sustain democratic dividends (such as roads, communication, health facilities), and deploy resources to empower citizens through education and other means -with a view to empowering the public at the grassroots and enabling it to play its key roles in the democratization processes- under the context of widespread corruption. ${ }^{50}$

\footnotetext{
${ }^{44}$ Nsongurua J. Udombana (2003), 'Articulating the Right to Democratic Governance in Africa', Michigan Journal of International Law, Vol. 24, Issue 4, pp.1272-1273.

${ }^{45}$ Ibid.

${ }^{46} \mathrm{Id}$. at 1276

${ }^{47} \mathrm{Id}$. at 1277 .

48 Ibid.

${ }^{49} \mathrm{Id}$. at 1278 .

${ }^{50} \mathrm{Id}$. at $1281-1282$.
} 


\subsection{The challenges posed by divided society}

African countries are not homogenous, and they host plural societies which have remained a challenge to democratization. ${ }^{51}$ As Udombana notes, it is much easier to create stable democracies in societies that have social homogeneity and political consensus. ${ }^{52}$ Yet, it is possible to create stable democracies and enhance democratization using mechanisms such as 'consociational democracy' as formulated and articulated by Arend Lijphart. ${ }^{53}$ Hence, it is imperative for African states to promote pluralism, protect human rights, maximize the participation of individuals in decision making at various levels. ${ }^{54}$

\subsection{Aid dependency and foreign debts}

The nature and pace of democratization is not within the sole authority of African states because external influences in the form of loan, aid and debts have far reaching impact. ${ }^{55}$ That is why writers argue that democratization cannot ensure good governance and prosperity unless Africans learn to neutralize the harm that loans, aid and debts have done to them. ${ }^{56}$ When states depend on unearned income, they ignore accountability ${ }^{57}$ since they develop the tendency to become accountable towards their main source of income, including policies such as improper currency devaluation in spite of its adverse impact where imports significantly dominate the balance of trade.

Hegemonic involvement of external actors directs accountability outwards. Conditioned aid is detrimental to democratization since the democratization project in Africa cannot hinge solely on the careful strategies of African governments, but also on the good will of donors. ${ }^{58}$ By and large, debt burden in Africa has become the greatest threat to democratization. This is because the heavy debt burden and debt servicing obligation has weakened the socio-economic structure of many African

${ }^{51}$ E. Ike Udogu (1999), 'The Issue of Ethnicity and Democratization in Africa: Toward the Millennium', Journal of Black Studies.

${ }^{52}$ Nsongurua J. Udombana (2003), 'Articulating the Right to Democratic Governance in Africa', Michigan Journal of International Law, Vol. 24, Issue 4, p. 1281.

${ }^{53}$ Arend Lijphart (1969), 'Consociational Democracy', World Politics, Vol. 21, No. 2, (Jan., 1969), pp. 207-225.

${ }^{54}$ Udombana, supra note 52, at 1283.

55 Muna Ndulo (2003), 'The Democratization Process and Structural Adjustment in Africa', Indiana Journal of Global Legal Studies, Vol. 10, Issue 1, (Winter 2003).

${ }^{56}$ Udombana, supra note 52, at 1283.

${ }^{57} \mathrm{Id}$. at 1284.

58 See Stephen Brown (2005), 'Foreign Aid and Democracy Promotion: Lessons from Africa', The European Journal of Development Research, Vol.17, No.2, pp. 179-198. 
countries. It has also become a constraint to Africa's prospects for economic growth. Furthermore, it has also eroded the ability of African countries to fulfil socio-economic and cultural rights to their citizens. ${ }^{59}$

\section{The Role of Traditional Institutions in the Democratization Process: An Overview}

It is argued that the democratization process in Africa should be contextualized and the autochthonous leaders and institutions should be incorporated into the modern governance so that democratization can become fruitful. However, since the nature of the relationship between traditional leaders and institutions in post-colonial states is ambiguous, it has remained to be a recurring theme in post-independence Sub-Saharan Africa. ${ }^{60}$ The root cause of this challenge dates back to the colonial system of governance, which incorporated traditional leaders as an extension of colonial regimes using direct and indirect forms of rule. Such incorporation was aimed at extracting human and natural resources and curbing organized resistance against the colonial masters. ${ }^{61}$

Although certain traditional leaders have positively contributed in the struggle against colonialism, post-independence governments did not embrace traditional institutions in the administration of the state. Rather, the traditional leaders were seen as repressive collaborators of the colonial masters and as impediments to the modernization and nation building endeavours of the 1960s and 1970s. For instance, Tanzania and Mozambique banned traditional leaders altogether while the majority of states circumscribed the legal powers of the traditional leaders in local governance, limiting their roles to cultural and spiritual activities. ${ }^{62}$

After the 1990s, the attitude of African governments towards traditional leaders has changed, owing to the wave of democratization. Thus, 'retraditionalisation' has emerged resulting in the reversal of the previous misperception of traditional authorities as negative forces. In effect, Sub-

59 Maleshoane Lekomola (2010), 'The African Debt Dilemma: An Overview of Magnitude, Causes, Effects and Policy Options', Journal of American Science, Vol. 6, No.3, pp. 63-69.

60 Helene Maria Kyed and Lars Buur, 'Introduction: Traditional Authority and Democratization in Africa', in Lars Buur and Helene Maria Kyed (ed.) State Recognition and Democratization in Sub-Saharan Africa: A New Dawn for Traditional Authorities? Palgrave Macmillan, 2007, p.1.

${ }^{61}$ Ibid.

${ }^{62}$ Ibid. 
Saharan Africa saw the resurgence and enlargement of the roles of traditional authority in local governance, development and national politics. Traditional leaders have been drawn into the mainstream processes of nation building and democratization in various ways. ${ }^{63}$

The wave of democratization in (post-1990s) Africa and the adoption of multiparty democracy has opened up new public spaces for traditional leaders. For instance, in Malawi, ${ }^{64}$ Mozambique ${ }^{65}$ and Zambia, ${ }^{66}$ official commitments to decentralization have resulted in the formal incorporation of the role of traditional leaders in local governance. In countries such as Niger and Ghana, the democratization process has gone to the extent of opening up ways for traditional leaders to stand as candidates in local government. ${ }^{67}$

The democratization role of traditional leaders has been supported by a number of intellectuals and politicians in countries such as Mozambique and South Africa during their revision of legislation combined with broader celebration of 'Africanness. ${ }^{\text {"68 }}$ The supporters of such legislation considered traditional leaders as 'authentic' African forms of democratic governance, as the genuine representatives of rural African communities and as culture cores serving as foundation stones on which a genuine sense of nationhood could be built. Nonetheless, there has been a modernist position which is skeptical towards the recognition and incorporation of the traditional authority into the 'modern' form of governance since it is believed that traditional authority is anti-democratic. The skepticism is also based on the belief that what might be regarded as a real pre-colonial tradition has withered away because of colonial impositions. ${ }^{69}$

${ }^{63} \mathrm{Id}$. at 2.

${ }^{64}$ Asiyati Lorraine Chiweza, 'The Ambivalent Role of Chiefs: Rural Decentralization Initiatives in Malawi', in Lars Buur and Helene Maria Kyed (ed.), State Recognition and Democratization in Sub-Saharan Africa: A New Dawn for Traditional Authorities? Palgrave Macmillan, 2007, pp. 53-78.

${ }^{65}$ Lars Buur and Helene Maria Kyed, 'Traditional Authority in Mozambique: The Legible Space between State and Community', in Lars Buur and Helene Maria Kyed (ed.), State Recognition and Democratization in Sub-Saharan Africa: A New Dawn for Traditional Authorities? Palgrave Macmillan, 2007, pp. 105-130.

${ }^{66}$ Wolfgang Zeller, "Now we are a Town": Chiefs, Investors, and the State in Zambia's Western Province, in Lars Buur and Helene Maria Kyed (ed.), State Recognition and Democratization in Sub-Saharan Africa: A New Dawn for Traditional Authorities? Palgrave Macmillan, 2007, pp. 209-233.

${ }^{67}$ Christian Lund (2001), 'Precarious Democratization and Local Dynamics in Niger: Cases of Local Politics in Zinder', in Development and Change, 32 (5): 845-69.

${ }^{68}$ Kyed and Buur, supra note 60 , at 8 ,

${ }^{69} \mathrm{Id}$. at 9 . 
Despite the arguments of the modernist skeptics, it is believed that the informal traditional authorities remain significant to the democratization process in the continent. This is because, as studies reveal, traditional institutions still play very useful roles in dispute resolution and ensuring equitable access to land in rural areas. ${ }^{70}$ As Frémont observes, several liberties such as liberty to religion, liberty of association, freedom of expression, the right to participate in affairs of state and freedom of movement are recognized by traditional institutions. ${ }^{71}$

Traditional institutions are also known for a decentralized participatory decision making system which empowers local communities to make local decisions in matters of self-governance. ${ }^{72}$ African traditional institutions have village councils which give communities the chance to resort to the exercise of direct democracy. Besides, there are periodic public meetings that deal with major social and economic issues of the village. ${ }^{73}$ In traditional African institutions, conflicts are resolved via negotiation. Negotiated political solutions are used to resolve ethnic conflicts. As Semahegn indicates, there are instances where conflicts among state political parties can be resolved by traditional conflict resolution mechanisms. ${ }^{74}$

In spite of the values of traditional African institutions, there are certain challenges to their development and continuity that undermine their roles in the democratization process. The first relates to the crude implementation of Western institutions in disregard of traditional African institutions which has resulted in weakening the development of these institutions. Such approach has, it is argued, harmed democratic transformation in the continent. The second challenge is attributable to some aspects of 'globalization' that erode the value of traditional institutions. Unexamined reception of Western culture (as a package rather than careful synthesis) is pervasive in every corner of the continent. This induces the young generation to ignore the usefulness of traditional institutions. ${ }^{75}$ The attitude of the African elites

${ }^{70}$ See Semahagn Gashu (2013), 'The Relevance of African Culture in Building Modern Institutions and the Quest for Legal Pluralism', Saint Louis University Law Journal, Vol. 57, p. 438.

${ }^{71}$ Jacques Frémont (2009), 'Legal Pluralism, Customary Law and Human Rights in Francophone African Countries', Victoria University Wellington Law Review, Vol. 40, p. 156.

72 Semahegn, supra note 70 , at 438.

${ }^{73}$ Ibid.

${ }^{74}$ Ibid.

${ }^{75}$ See Sammy Adelman (1998), 'Constitutionalism, Pluralism and Democracy in Africa', Journal of Legal Pluralism \& Unofficial Law, Vol. 42, p. 80. 
towards these institutions aggravates the challenge. The other challenge to the development of traditional institutions is associated with absence of accountability and discriminatory practices within some customs in Africa. ${ }^{76}$

\section{Concluding Remarks}

Following independence from colonialism, aspiration of Africans was democratization. On the contrary, the era of colonialism was soon replaced by despotism, at least during the first three decades after independence- from the early 1960s until end of the 1980s. Starting from the late 1980s, there were stern movements for democracy and democratization motivated by internal and external factors. It is possible to conclude that these movements have played important roles in the democratization process. Although the achievements in various African countries vary, there have been encouraging trends of democratization in many parts of the continent. However, these gains are accompanied by various shortfalls because there are serious rollbacks in the pace of democratization in several African countries.

Despite the positive moves towards democratization, there are various challenges and obstacles (highlighted in the preceding sections) which obstruct democratization in the continent. The major challenges and obstacles include institutional challenges, foreign interventions, ethnicity, poverty, corruption, military intervention, aid dependency, foreign debt burden and widespread illiteracy. It is thus high time for African countries to aggressively work towards democratization by overcoming these challenges and obstacles. In the course of dealing with the these challenges and impediments to realize democratization, this author shares the views and findings in various literature that the Western institutions, which are basically befitting to liberal democracy, need to be adapted to the African cultural, social and economic reality so that democratization would be successful in the continent. In other words, resort to contextualization and 'autochthonization' is indispensable. To this end, the role of traditional institutions should be given appropriate attention to the extent necessary and in a manner that it is compatible with the international human rights conventions to which most African countries are parties.

\footnotetext{
${ }^{76}$ Semahegn Gashu, supra note 70 , at 441.
} 